\title{
THE SOURCE OF' 'THE MIDDLE ENGLISH PROSE ST. ELIZABETH OF SPALBECK.
}

In 1885 Horstmann edited in Anglia ${ }^{1}$ ) four saints' lives in 15th century prose from MS. Douce 114. As the source of the first of these, a Life of St. Elizabeth of Spalbeck (or, as she is perhaps more commonly designated by hagiographers, of Erkenrode), he referred to a Latin vita by "Dan Philippe of Clareualle". It was thus that the translator transcribed the author's name. "Diese latein. vita ist bisher nicht bekannt", said Horstmann.

As far as printed texts were concerned, the editor was quite correct in his statement. It was not until four years later, as a matter of fact, that Philip of Clairvaux's interesting account of the Belgian ecstatic was printed by the Bollandists. Since it has long been accessible, ${ }^{2}$ ) however, the fact ought to be noted, while a brief summary of the differences between the Latin and the English versions may serve to throw some light on the methods of fifteenth century translators. The Latin text is based on two MSS., both of which are good copies of the work. One of them is in the Bibliothèque Royale at Brussels, ${ }^{3}$ ) the other in the Académie at Liège. ${ }^{4}$ ) As the Cistercian house of Erkenrode was situated only six or seven miles from Liège, this second MS. has the fortuitous

1) VIII, 102-196.

2) Catalogus codicum hagiographicorum Bibliothecae Regiae Bruxellensis II (1889), 362-378.

3) Cod. 2864-71.

4) Cod. 135. 
interest of having remained close to the scene of St. Elizabeth's extraordinary manifestations.

In general, it may be said that the translation of Philip's vita was intelligently made. The "compilour", as he called himself after the fifteenth century fashion, seldom misunderstood his original, and took few liberties with it save by way of abridgment. Although he remarked ${ }^{1}$ ) in his prefatory apology that he "neiper can ne purposis to folowe pe wordes, but vnnepis and wip harde pe sens", he actually succeeded in translating the Latin quite closely into idiomatic English. Except for the passages which I shall cite, he followed his expressed plan of "neiper puttinge to nor doynge awaye any clauses pat schulde chaunge pe substaunce of pe story, but opere-while leuyng legeauns and auctorites of holy writte". His omission of rhetorical flourishes and of scriptural quotations does not "chaunge pe substaunce" in any way, while his other abridgments were made with such good sense that the story is not interrupted.

The following are the passages of the Latin work omitted, according to the sections of the Bollandists' edition. When the breaks occur within sections, I add the pages and lines from - the same edition for readier reference. $\S 1$ (Prologue); $\$ 5$ (p. 365, l. 35) - §6 (p. 367, l. 6); § 8 (p. 368, 1l. 32-37); $\S 10$ (p. 370, 1l. 5 and 6 , one sentence); $\S 14$ (p. 371, 1l. 28-32); $\S 15$ (p. 371, l. 32) - §16 (p. 373, l. 15); § 25 (p. 376, l. 35) - §28 (p. 378, l. 3).

I add a few notes on the English text, as printed by Horstmann.

P. 109, 1.11. "as sche wolde pulle oute her chaules" added by translator.

P. $109,1.20$. Horstmann suggested the emendation of "puttis" to "pullis"; but "puttis" is a satisfactory translation of the original "pulsat".

P. 109, 1. 30. "ioy", which Horstmann found absurd, translates "jubilum". The "jubilus" or "neuma" was the longdrawn utterance of the final syllable of an antiphon or any similar chant. See Ducange, under "jubilus". The author, as is suggested to me by Professor D. Magie Jr., must have used the word of Elizabeth's ecstatic cries, while the translator

1) Anglia VIII, 107.

Anglia. N. F. XXVU. 
rendered the passage "ioy for a sawtry" in default of any more technical English equivalent.

P. 109, 1. 31. "wrast" for "plectrum" is a comparatively rare word and deserves noting.

P. 110, 11. 8 and 9. "'zouche here, zouche heere', pat is to sey in Englysche: swete loord, swete lord." This is the only specimen of the saint's vernacular in the work. It appears in the Brussels MS. as "Here, soete Here, id est Domine, dulcis Domine"; and in the Liège MS. as "Zuete Hyere, id est douce Siere".

P. 112, 1.12. Horstmann's emendation of "as if pere" for "opere" is assured by the Latin.

P. 112, 1.20. Either through misunderstanding or because he had a faulty text before him, the translator renders "formam crucis" by "same form", which makes nonsense of the sentence.

P. 113, 1. 35. "oures", which Horstmann found so absurd that he marked it with a point of exclamation, should stand. The Latin is "praeter horas".

P. 114, 1l. 12 and 19. The translator by a curious misunderstanding renders "maxillas" and "maxillam" by "pappys" and "pappe" respectively. This makes nonsense, of course." Since he elsewhere translates "maxilla" correctly, it may be that this error had crept into the text he was using.

P. 114, 1. 14. Horstmann's emendation of "pan" to "pat" is justified.

P. 114, 1. 40. "Trudous" should be "Trudons", as Horstmann suggested. The Latin is "Trudonis".

P. 116, 1. 14. Philip calls his servant who could talk with the saint in her native speech "Theutonicus seu Brabantinus", which becomes "a Braban" in the English.

P. 116, 1. 20. For "entermete" the Latin has "intromitterem".

P. 118, 1.9. The translator renders "coabbas noster" by "pe abbot" simply.

P. 118, 1. 42. Horstmann's emendation of "weiknesse" for "werknesse" is justified.

Princeton University, U.S. A.

Gordon Hall Grrould. 